\title{
Information Technology in Sports Clothing
}

\author{
M Iffan ${ }^{1 *}$, M R Khoirul ${ }^{2}$ \\ ${ }^{1}$ Departemen Manajemen, Universitas Komputer Indonesia, Indonesia \\ 2Departemen Ilmu Komunikasi, Universitas Komputer Indonesia, Indonesia \\ Email: *m.iffan@email.unikom.ac.id
}

\begin{abstract}
The purpose of this study, to meet the needs of Muslim women to carry out exercise activities so that Muslim women do not struggle to find clothes that fit their style in everyday life, using Social media as a tool for promotion. This study used a descriptive method to describe the efforts of Muslim women's sports clothing through social media as a promotional tool because nowadays many women who already use hijab during exercise. The results obtained from this research added employment opportunities. The reason to be accomplished and get noticed is the clarity of the utilization of social media and see what is being needed by women today. The conclusion of this research is young people especially those who have not opened the business, this business is used as an example or the first step of opening the daily effort to increase income and learn to become a professional entrepreneur.
\end{abstract}

\section{Introduction}

As we know it, nowadays, sports have got a lot of interest. Nowadays, women prove that they can do anything men do, one of them is sports. Women also prove that the hijab does not get in the way to exercise. Noore is a simple and usable brand for those who are active in sports so that Muslim women do not struggle to find clothes that fit their style in everyday life. Noore also provides the PRoin hijab to facilitate the hijab users in exercising. It is because many hijab women do not use clothes that should be used when exercising.

The form of entrepreneurship and examining how intrapreneur and corporations can work together for mutual benefit. Innovation is crucial to sustainable commercial vitality and large organizations often have the idea and resources to implement innovation. A solution is an entrepreneur person who takes direct responsibility for creating innovations in the organization [1]. Previous research results suggest that internet activity, such as using the Internet to socialize, seek pleasure and search for information, as well as using the positive media correlates with various social support dimensions [2]. If the brands continue to struggle to benefit by delivering new value to customers through products and services Customer management, retail strategy, and innovative marketing mix should be improved. However, the inclusion of many brands coupled with the decline in sales associated with economic downturns has led to a new challenge for luxury corporations [3]. The phenomenon of social media, which can now significantly affect the reputation, sales, and even resilience of the company. Moreover, many executives are away from or neglect this form of media because 


\section{International Journal of Research and Applied Technology}

$1(2)(2021) 278-282$

Journal homepage: https://ojs.unikom.ac.id/index.php/injuratech

they do not understand what it is, the various forms that can be taken, and how to engage in learning because. Different social media activity is determined by as far as where they focus on a few [4]. Social Media is a means for consumers to various information text, images, video, and audio with each other and the company and vice versa. Social media is an online media with its users that can easily participate, share, and create content including blogs, social networks, wikis, forums, and virtual worlds. Social Media can have a positive or negative function, depending on its use [5].

Hijab fashion continues to grow in many Muslim countries including Indonesia. Hijab variation is also growing, following the needs of the people and one of them is to exercise. Hijab Sport product brands are available in various brands, ranging from local to international brands. The purpose of this research is to identify factors that can influence the intention of purchasing hijab Sports products in Hijab Muslim women [6]. Hijab is not only an obligation for Muslim women but also become a trend favored by Muslim women and can give a picture to the community as to what the concept of Muslim women following the teachings and rules of Islam [7]. The purpose of the hijab trend and this religious view in every human life there is always local wisdom. At the very least, wisdom can appear on thought, attitudes, and behavior. All three are almost difficult to separate. If the three are lame, then the local wisdom is increasingly faded [8]. It is also can be considered as the cover for Muslim women. Therefore, it looks interesting and different from the usual fashion photography work. Also introducing fashion hijab that is not monotonous and can be an option for women wearing hijab in matching the clothes [9]. In the end, women's hijab in this context still can not escape the myth of beauty. Religious norms were compromised with modernity and commercial cannot eliminate the existing myth [10].

The purpose of this research is to fulfill the needs of Muslim women to exercise activities. This research used a descriptive method. From the above studies, it can be concluded that this study discusses the progress of the Internet with an increasingly advanced social media that is Instagram. Therefore, by looking at the progress of social media Instagram, hijab women can now get information about the existence of hijab sports needed. Advances in technology that are increasingly sophisticated and rapid are very profitable for many parties, especially Muslim women who exercise.

\section{Method}

The method used is a descriptive method to observe objects and to find knowledge throughout the study especially in social media that nowadays has been a human lifestyle. Therefore, social media facilitates the business and communication to consumers.

\section{Results and Discussion}

Social Media is an effective business promotion tool because it can be accessed by anyone and anywhere so that promotion can be wider. Social Media has a very important role for both large and small companies. Every social media has its advantage for businesses as opposed to print media as a tool to promote its products. Noore was formed to meet the needs of Muslim women in exercising [2]. Besides, Noore's interpretation of the latest collection of capsules dedicated to them being a simple urban sport mode that provides plenty of room for freedom and also expression and daring to be different. Figure 1 below shows the homepage view. 


\section{International Journal of Research and Applied Technology}

$1(2)(2021) 278-282$

Journal homepage: https://ojs.unikom.ac.id/index.php/injuratech

a

NO@RE'

HUAB tOPS BOTTOM OUTERWEAR SWIMWEAR ACCESSORIES SALE SIZE CHART NOORE LIMITED WARRANTY

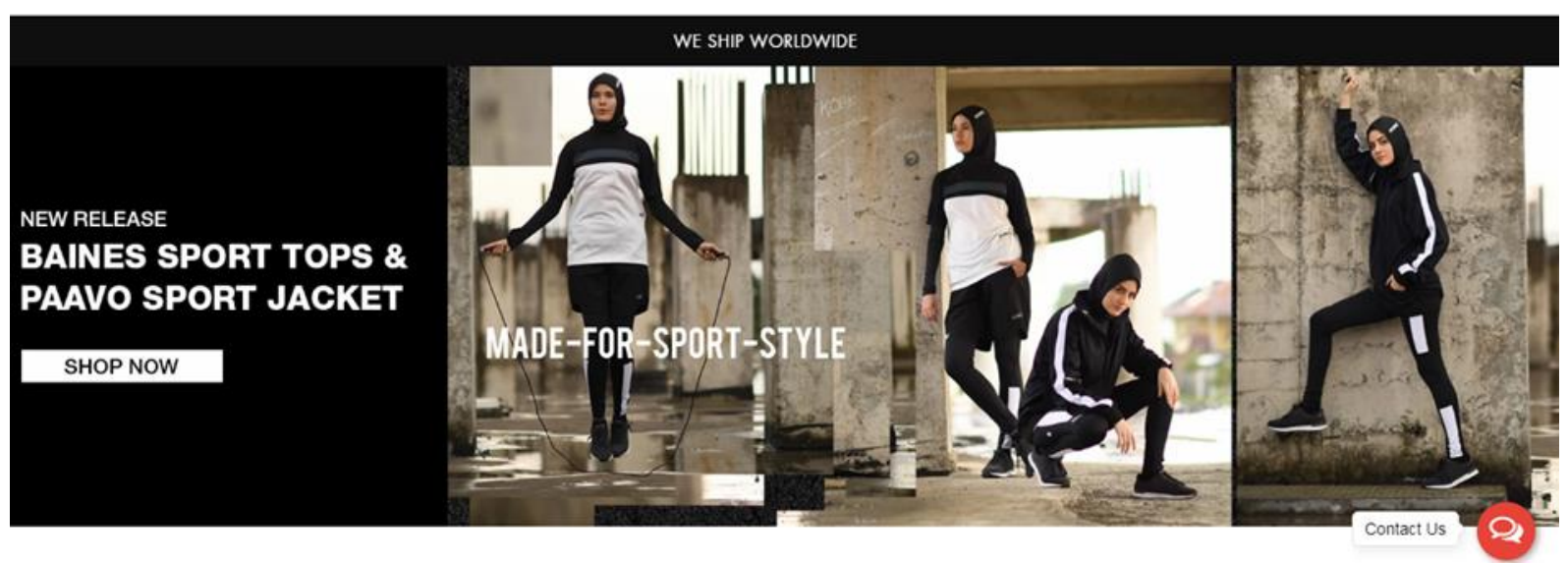

Figure 1. Home View.

Figure 1 shows that the look of the website, which has a combination of colors that are not so striking but still look simpler. Besides, Noore also uses Instagram as a tool for promotion. Figure 2 below shows the Instagram page.

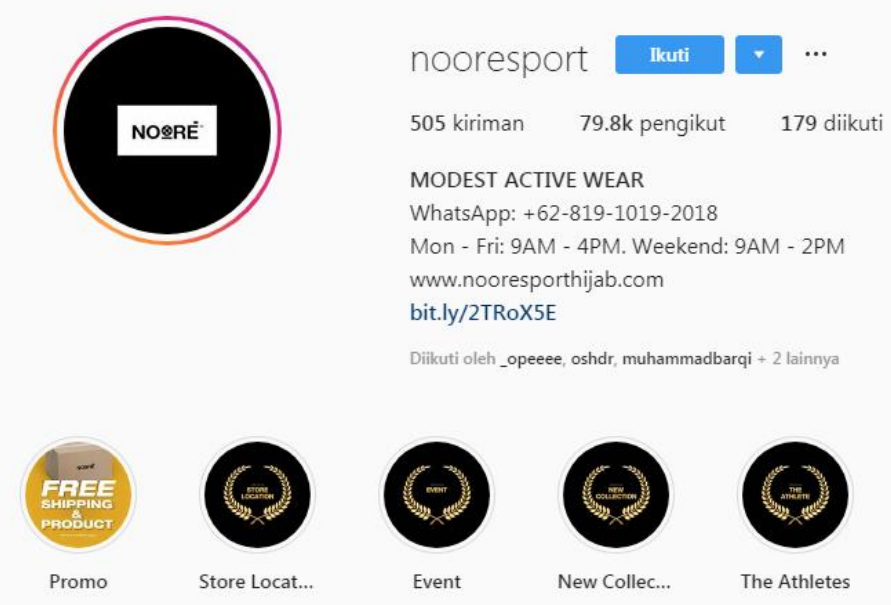

Figure 2. Instagram as a promotional tool.

Figure 2 shows that Instagram is also a tool for promotion. Through the social media promotion process, a wide range of products can be much easier and efficient. Figure 3 below shows Nooresport page. 


\section{International Journal of Research and Applied Technology}

$1(2)(2021) 278-282$

Journal homepage: https://ojs.unikom.ac.id/index.php/injuratech
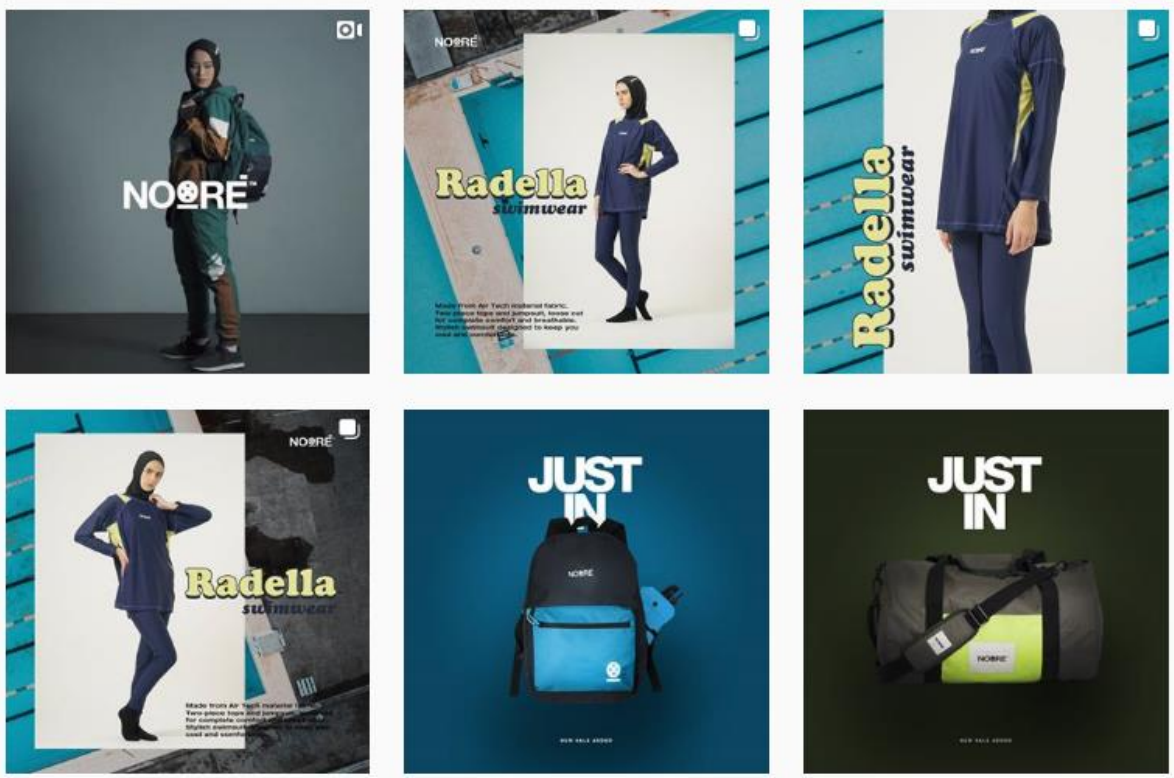

Figure 3. Nooresport as promotional Media.

Figure 3 shows that using the social media promotion process a wide range of products so that it can be much easier and efficient. There is a wide range of products from Noore. Figure 4 below shows a variety of products view.
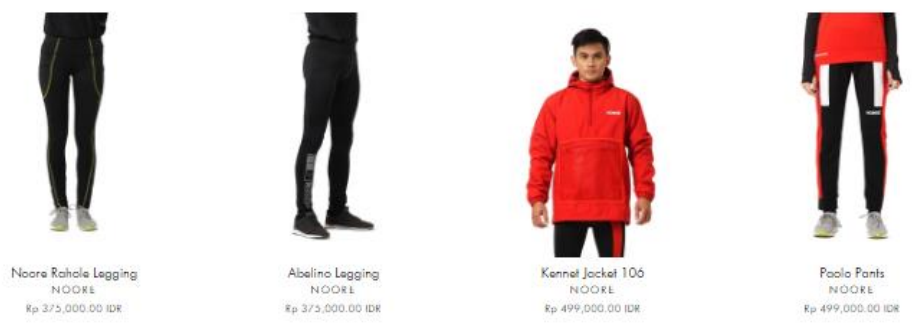

Noore Hijab
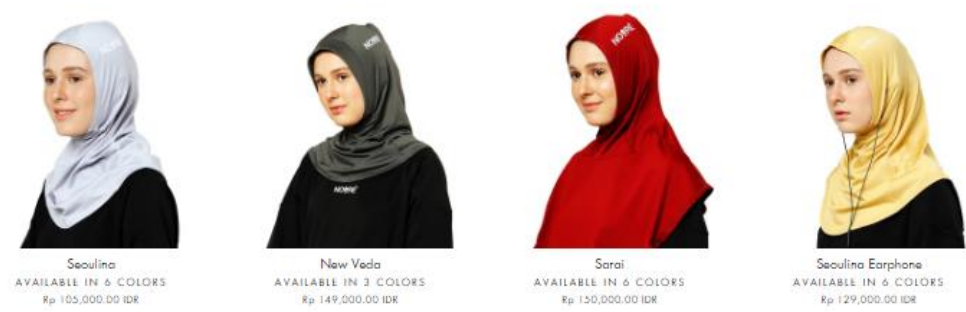

Figure 4. Wide range of products.

Figure 4 shows that there are various products from Nooresport including leggings and Hijab sport. Not only Hijab that makes Noore famous or identical to his Hijab but also there is a wide range of products sold such as jackets, sweaters, cuffs, and other sportswear. 
International Journal of Research and Applied Technology

1(2)(2021) 278-282

Journal homepage: https://ojs.unikom.ac.id/index.php/injuratech

\section{Conclusion}

Advances in technology or social media development make the actors or companies compete to be the best. The goal is to achieve the vision and mission for the company as a sign follows the era of digital marketing. Nowadays, sales through online media mainly through social media is Instagram has been followed by small companies to compete and make their company as a big name company.

\section{Acknowledgement}

We would like to thank to those who helped the process of making this paper.

\section{References}

[1] Portales, L. 2019. Social Intrapreneurship, the Main Factor of Social Innovations Within Traditional Companies. In Social Innovation and Social Entrepreneurship, pp. 147-160. Palgrave Macmillan, Cham.

[2] Koesters, T. C., Ballouli, K., Bernthal, M. J., \& Hansell, S. 2016. Bowling for dollars: establishing perceived need and brand equity in a participatory sport. Sport Marketing Quarterly, 25(1), pp.62.

[3] Ko, E., Phau, I., \& Aiello, G. 2016. Luxury brand strategies and customer experiences: Contributions to theory and practice. Journal of Business Research, 69(12), pp.57495752.

[4] Choi, D. S., \& Sung, C. S. 2017. The Influence of Information Technology Competence on Entrepreneurial Attitude and Entrepreneurial Intention. Journal of Information Technology Services, 16(1), pp. 27-39.

[5] Kaplan, A. M., \& Haenlein, M. 2016. Higher education and the digital revolution: About MOOCs, SPOCs, social media, and the Cookie Monster. Business Horizons, 59(4), pp. 441-450.

[6] Keshkar, S., Lawrence, I., Dodds, M., Morris, E., Mahoney, T., Addesa, F., ... \& Naylor, M. 2018. The Role of Culture in Sports Sponsorship: an Update. Annals of Sport Science, 6(4), pp.14-22.

[7] Khair, N. 2019. Reinterpretation Of Hijab Concept In The View Of Murtadha Mutahhari. Journal of Scientific Student Raushan Fikr, 8(1),p. 99-119.

[8] Wardiani, S. R. 2019. Muslimah's Clothing Brand, Identity, And Myths In Barthes Semiotic Study. El Harakah, 21(1), pp. 83.

[9] Arrigo, E. 2018. Social media marketing in luxury brands: A systematic literature review and implications for management research. Management Research Review, 41(6), pp,657-679.

[10] Martín-Consuegra, D., Díaz, E., Gómez, M., \& Molina, A. 2019. Examining consumer luxury brand-related behavior intentions in a social media context: The moderating role of hedonic and utilitarian motivations. Physiology \& behavior, 200, pp.104-110. 